\title{
STYL GATUNKOWY KONSTYTUCJI
}

\author{
EWA MALINOWSKA, \\ Zakład Stylistyki, Instytut Polonistyki \\ i Kulturoznawstwa, Wydział Filologiczny \\ Uniwersytet Opolski \\ ewamal@uni.opole.pl
}

\begin{abstract}
Abstrakt: W opracowaniu przyjmuję rozumienie gatunku jako modelu określonego typu tekstu. Rozpatruję więc gatunek jako wzorzec tekstu, na który składają się wszystkie jego płaszczyzny (formalna, poznawcza, pragmatyczna, aksjologiczna, stylistyczna). Interesuje mnie przede wszystkim płaszczyzna stylistyczna konkretnego zdarzenia komunikacyjnego, jakim jest tekst obowiązującej dziś ustawy zasadniczej, tj. Konstytucji RP (1997 r.).Konstytucja w wymiarze stylistycznym jest wielobarwna. Dominuje władczy suchy styl normatywny z wysoką frekwencją nakazów, obowiązków i uprawnień, ale, w przeciwieństwie do innych gatunków sfery urzędowo-prawnej, silnie obecne są też elementy wysokiego, kunsztownego stylu retorycznego realizowanego nie tylko $\mathrm{w}$ preambule, ale także $\mathrm{w}$ uroczystych aktach ślubowań prezydenta i posłów. Te swoiste teksty w tekście podkreślają doniosłość konstytucji jako najważniejszego dla wspólnoty państwowej aktu prawnego. Na styl gatunkowy konstytucji mają również wpływ przekonania ideologiczne podmiotu prawodawczego.
\end{abstract}

Slowa kluczowe: gatunek, konstytucja, styl normatywny, styl retoryczny 


\title{
GENRE STYLE OF CONSTITUTION
}

\begin{abstract}
In this paper I take the meaning of genre as a model of a specified type of text. Therefore, I consider genre as a pattern of the text, which consists of all its planes (formal, cognitive, pragmatic, axiological, stylistic). I am especially interested in the stylistic plane of a concrete communicative event, which is the current text of the fundamental law, i.e. of the Constitution of the Republic of Poland (1997). The constitution in the stylistic dimension is multi-colour. A normative dry imperious style is dominant, with a high frequency of orders, duties and rights, but contrary to the other genres of official and legal spheres, there are also strongly present elements of high, elaborative rhetoric style executed not only in the preamble, but also in the solemn acts of president's and MPs' oaths. These particular texts in the text underline the significance of the constitution as the most important legal act for the state community. The ideological convictions of the legislative body have also an influence on the genre style of the constitution.
\end{abstract}

Keywords: genre, constitution, normative style, rhetoric style

\section{Wprowadzenie}

W niniejszym opracowaniu, korzystając z osiągnięć współczesnej genologii lingwistycznej, przyjmuję rozumienie gatunku jako modelu określonego typu tekstu (Gajda1993, Malinowska 2012, Witosz 2005, Wojtak 2004). Rozpatruję więc gatunek jako wzorzec tekstu, na który składają się wszystkie jego płaszczyzny (komponenty):

- formalna (struktura tekstu),

- $\quad$ poznawcza (tematyka i sposób jej przedstawienia),

- $\quad$ pragmatyczna (uwikłania komunikacyjne),

- $\quad$ aksjologiczna (hierarchia wartości),

- $\quad$ Stylistyczna (szerzej Wojtak 2004: 17-40).

Interesuje mnie aktualizacja wzorca gatunkowego konstytucji, czyli przejście od abstrakcyjnego modelu do konkretnego zdarzenia komunikacyjnego, jakim jest tekst obowiązującej dziś ustawy zasadniczej, tj. Konstytucji RP, uchwalonej w 1997 r.

Wzorzec gatunkowy konstytucji krystalizował się w praktyce dyskursywnej od schyłku XVIII wieku aż do czasów współczesnych (szerzej o ewolucji gatunku Malinowska 2012). Wszystkie komponenty 
wzorca (strukturalny, pragmatyczny, poznawczy, aksjologiczny oraz stylistyczny) decydują o jego specyfice, wszystkie mają wpływ na ostateczny kształt gatunku, wzajemnie się warunkują. Jednak to komponent stylistyczny przenika wszystkie płaszczyzny wzorca, nadając całości charakterystyczny styl gatunku, można nawet powiedzieć - styl gatunkowy (Wojtak 2007). Celem referatu jest wskazanie najważniejszych wyróżników stylu konstytucji jako gatunku o najwyższej mocy prawnej i wysokim prestiżu komunikacyjnym. Ta szczególna moc prawna konstytucji polega na tym, że zajmuje najważniejsze miejsce w systemie źródeł prawa, jej normy są nadrzędne w stosunku do norm ustaw zwykłych (Sagan 2003: 19).

Cechy stylistyczne ustawy zasadniczej są uwarunkowane przede wszystkim pragmatycznie, wynikają z warunków komunikacji i relacji między jej uczestnikami, związane są także z celem komunikacyjnym. Odbiorcami ustawy konstytucyjnej są wszyscy obywatele państwa oraz organy państwa. Konstytucja jako akt prawny powszechnie obowiązujący tworzy bowiem rzeczywistość prawną (pewne normatywne stany rzeczy) dla całej społeczności państwa (por. Wronkowska 2007: 158). Specyficzny jest nadawca (twórca) tekstu konstytucji - jest nim prawodawca konstytucyjny. Nie jest to jedna konkretna osoba, bowiem $\mathrm{w}$ procesie tworzenia prawa o doniosłości generalnej uczestniczą 3 grupy podmiotów, których role są zróżnicowane: 1) podmiot przygotowujący merytorycznie i redakcyjnie projekt (tu Komisja Konstytucyjna powołana przez sejm - do niej wpływają projekty różnych ugrupowań i sił politycznych, tu następuje tzw. ucieranie konstytucji), 2) podmiot podejmujący decyzje prawotwórcze (parlament) i 3) podmiot promulgujący, czyli ogłaszający tekst (prezydent). W przypadku ustawy zasadniczej mamy jeszcze jeden podmiot: naród, który ma prawo do zaaprobowania lub odrzucenia treści konstytucji $\mathrm{w}$ referendum (instytucja referendum konstytucyjnego pojawiła się dopiero przy uchwalaniu Konstytucji PRL w 1952 r.).

Twórcy ustawy konstytucyjnej z 1997 r. podmiotem władzy zwierzchniej czynią „Naród Polski”, wskazując, że najważniejszym podmiotem i suwerenem państwa są jego obywatele, a konstytucja winna stać się spoiwem łączącym wszystkich obywateli „w trosce o naprawdę jedyne wspólne dobro, jakim jest dobro Rzeczypospolitej" (z listu ówczesnego prezydenta - Aleksandra Kwaśniewskiego do obywateli przed referendum konstytucyjnym). 
W przypadku konstytucji trudno mówić o jednej dominującej funkcji tekstu, zauważa się ścisły związek funkcji tekstu z jego strukturą. W części zasadniczej obserwujemy współwystępowanie funkcji stanowiącej i regulującej (dyrektywnej), natomiast dla wstępów konstytucyjnych charakterystyczna jest funkcja perswazyjna. Intencją twórcy wstępu konstytucyjnego jest nakłonienie odbiorców (całej wspólnoty państwowej) do przyjęcia konstytucji, do przyjęcia ustroju państwa oraz całego porządku prawnego i aksjologicznego. Stylistyka tekstu konstytucji jest zatem niejednorodna, ściśle związana jest z funkcją tekstu oraz jego dwudzielną strukturą. Wzorzec strukturalny omawianego gatunku można przedstawić następująco:

\section{Tytuł (nazwa gatunku) + preambuła (wstęp) + tekst zasadniczy}

Każdy z segmentów (poza tytułem) ma odmienną stylistykę. Na specyficzny styl gatunkowy konstytucji składa się więc cała wiązka cech oprócz normatywności i bezosobowości, jasności w określaniu kompetencji i zakresu działania organów państwa, które są charakterystyczne dla artykułowanego tekstu zasadniczego, zauważa się obecność eksponentów kunsztownego stylu retorycznego (zwłaszcza w preambule), podkreślających doniosłość konstytucji jako najważniejszego dla państwa i całej wspólnoty kulturowo-komunikacyjnej dokumentu prawnego. Wskażę teraz najważniejsze różnice między stylem tekstu artykułowanego konstytucji a stylem preambuły.

\section{Styl tekstu zasadniczego}

Przyjrzyjmy się najpierw tekstowi zasadniczemu. Prawodawca konstytucyjny stanowi prawo stanowczo, władczo, nie używa jednak form rozkaźnikowych, bowiem forma rozkaźnikowa „nie jest odpowiednia do formułowania norm adresowanych do ogółu podmiotów, jakie mają się znajdować w granicach państwa" (Ziembiński 1966: 42). Dominują stwierdzenia stanów rzeczy (konstatacje), np.:

- „Rzeczpospolita Polska jest demokratycznym państwem prawnym, urzeczywistniającym zasady sprawiedliwości społecznej" (art. 2). 
- „Ustrój Rzeczypospolitej Polskiej opiera się na podziale i równowadze władzy ustawodawczej, władzy wykonawczej i władzy sądowniczej" (art. 10. 1).

- „Godłem Rzeczypospolitej Polskiej jest wizerunek orła białego w koronie w czerwonym polu" (art. 28.1).

- „Kościoły i inne związki wyznaniowe są równouprawnione" (art. 25. 1).

- „Obywatelstwo polskie nabywa się przez urodzenie z rodziców będących obywatelami polskimi..." (art. 34. 1).

Najczęściej wypowiada się bezosobowo, zwłaszcza w wypowiedziach o charakterze dyrektywnym, np.:

- „Niedopuszczalne jest ograniczenie wolności i praw człowieka i obywatela wyłącznie z powodu rasy, płci, języka, wyznania lub jego braku, pochodzenia społecznego, urodzenia oraz majątku" (art. 233. 2).

- „Nikt nie może być dyskryminowany w życiu politycznym, społecznym lub gospodarczym z jakiejkolwiek przyczyny" (art. 32. 2).

- „Ekstradycja obywatela polskiego jest zakazana” (art. 55. 1).

- „Zapewnia się autonomię szkół wyższych na zasadach określonych w ustawie" (art. 70. 5).

Tekst konstytucji jest wypowiedzią nieskierowaną do kogoś, lecz wypowiedzią dla kogoś (Gizbert-Studnicki 1986: 58), wypowiedzią dla każdego członka wspólnoty państwowej. Znajduje to odzwierciedlenie $\mathrm{w}$ wysłowieniu norm konstytucyjnych, zwłaszcza w rozdziale II Wolności, prawa $i$ obowiązi człowieka $i$ obywatela. Warto zwrócić uwagę, że adresat normy konstytucyjnej jest wskazany zaimkiem $\boldsymbol{k a} \boldsymbol{a} \boldsymbol{d} \boldsymbol{y}$ w znaczeniu rzeczownikowym ‘każdy człowiek’ lub zaimkiem nikt w znaczeniu 'żaden człowiek’ z elipsą leksemu człowiek.Maciej Zieliński (2002: 148) wyjaśnia, że przyjęto konwencję użycia zaimka każdy jako nazwy oznaczającej człowieka. Natomiast, gdy przepis odnosi się do całego zbioru, tj. do wszystkich ludzi, używa się leksemu wszyscy, np.:

- „Wszyscy są wobec prawa równi. Wszyscy mają prawo do równego traktowania przez władze publiczne" (art. 32. 1). 
- „Każdemu zapewnia się wolność sumienia i religii” (art. 53. 1. ).

- „Każdy ma obowiązek przestrzegania prawa Rzeczypospolitej Polskiej" (art.83).

- „Każdy ma prawo do ochrony zdrowia” (art. 68).

- „Nikt nie może być poddany eksperymentom naukowym, w tym medycznym, bez dobrowolnie wyrażonej zgody" (art. 39).

Charakterystyczną cechą tekstu zasadniczego jest normatywność. Konstytucja jako najważniejszy akt prawny państwa „normuje sprawy dla społeczności państwowej najdonioślejsze" (Kompendium wiedzy o społeczeństwie, państwie i prawie 1999: 116), co znaczy , że normy konstytucyjne są normami najwyższej rangi, mają szczególną moc prawną. Ta szczególna moc prawna przesądza o nadrzędności konstytucji nad ustawami zwykłymi (Sagan 2003: 19). Normy konstytucyjne regulują ustrój polityczny państwa oraz podstawy jego ustroju społeczno-ekonomicznego. Określają formy sprawowania władzy państwowej, strukturę organów państwa, ich kompetencje oraz relacje z innymi organami. Wyznaczają także prawa i obowiązki oraz wolności obywatelskie. Ustawa zasadnicza tworzy pewne normatywne stany rzeczy dla całej społeczności państwa - zarówno dla wszystkich obywateli, jak i dla organów państwa. Adresatami norm konstytucyjnych są wiec nie tylko obywatele, ale też i organy państwa.

Wśród norm konstytucyjnych można wyróżnić normy kompetencyjne, tj. udzielające określonym podmiotom upoważnień do dokonywania rozmaitych czynności konwencjonalnych doniosłych prawnie, oraz normy nakazujące lub zakazujące albo zezwalające na określone zachowania w określonych sytuacjach. Normy kompetencyjne „wyznaczają sytuacje prawne dwóch podmiotów: jednego upoważniają do dokonywania czynności konwencjonalnych danego rodzaju, a drugiego zobowiązują, by na te czynności odpowiednio reagował" (Wronkowska 2003, 167). Podmiot uzyskujący kompetencję (podmiot upoważniony) to ten podmiot, który może $\mathrm{w}$ sposób ważny dokonywać określonych czynności konwencjonalnych w przeciwieństwie do innych podmiotów, które nie mają takiego upoważnienia. W ustawie zasadniczej normy kompetencyjne określają zakres upoważnień naczelnych organów władzy państwowej, np.: 
- „Marszałek Sejmu przewodniczy obradom Sejmu, strzeże praw Sejmu oraz reprezentuje Sejm na zewnątrz" (art. 110. 2.).

Innym typem norm są normy postępowania realizowane w wypowiedziach dyrektywnych, których charakterystyczną cechą jest to, że bezpośrednio nakazują bądź zakazują określonym podmiotom (adresatom), by w określonych okolicznościach w określony sposób się zachowały (Zieliński, Ziembiński 1992: 105).

Przepisy nakazujące formułowane są najczęściej za pomocą wyrażeń: musi, jest obowiązany, powinien, ma obowiązek, np.:

- „Władze publiczne sa obowiazane do zapewnienia szczególnej opieki zdrowotnej dzieciom, kobietom ciężarnym, osobom niepełnosprawnym i osobom w podeszłym wieku" (art. 68. 3.).

- „Każdy jest obowiązany do dbałości o stan środowiska...” (art. 86).

W konstrukcji zakazu dominują wyrażenia: nie może, nie wolno, jest zabronione, jest zakazane, np.:

- „Rzecznik Praw Obywatelskich nie może zajmować innego stanowiska, z wyjątkiem stanowiska profesora szkoły wyższej, ani wykonywać innych zajęć zawodowych" (art. 209. 2.)

- „Nie wolno zaciągać pożyczek lub udzielać gwarancji i poręczeń finansowych, w następstwie których państwowy dług publiczny przekroczy $3 / 5$ wartości rocznego produktu krajowego brutto..." (art. 216. 5.).

- „Zakazane jest istnienie partii politycznych i innych organizacji odwołujących się w swoich programach do totalitarnych metod i praktyk działania nazizmu, faszyzmu i komunizmu..." (art. 13)

W konstrukcji dozwolenia pojawiają się leksemy: może, ma prawo, np.:

- „Obywatel ma prawo do zabezpieczenia społecznego w razie niezdolności do pracy ze względu na chorobę lub inwalidztwo...(art. 67. 1.).

- „Każdy ma prawo do własności, innych praw majątkowych oraz prawo dziedziczenia (art. 64. 1.).

- „Prezes Rady Ministrów może zwrócić się do Sejmu o wyrażenie Radzie Ministrów wotum zaufania...” (art. 160). 
Najbardziej skonwencjonalizowanym składnikiem wypowiedzi dyrektywnej jest wyrażenie dyrektywalne (zob. Zieliński, Ziembiński 1992), które formułowane jest najczęściej w postaci:

Czasownik modalny + czasownik w bezokoliczniku nazywający czynność nakazaną lub dozwoloną

Np.: „Poseł może wyrazić zgodę na pociągnięcie go do odpowiedzialności karnej...” (art. 105. 4.)

\section{lub: Czasownik modalny + być + imiesłów bierny}

Np.: „Poseł nie może być pociągnięty do odpowiedzialności za swoją działalność wchodzącą $\mathrm{w}$ zakres sprawowania mandatu poselskiego..." (art. 105 1.).

Kolejną cechą stylu tego segmentu konstytucji jest dążenie do jednoznaczności, do precyzji. Andrzej Bałaban pisze, że postanowienia konstytucyjne powinny być jednoznaczne i dostatecznie szczegółowe, zwłaszcza we fragmentach przeznaczonych do bezpośredniego stosowania (Bałaban 1997, 9). Dążenie do precyzji szczególnie widoczne jest w normach prawnych, których adresatem są organy państwa. Bardzo szczegółowo określa się na przykład sposób wyboru prezydenta i jego uprawnienia. Przewiduje się też zachowania innych podmiotów w sytuacji, gdy prezydent nie może przejściowo sprawować swego urzędu:

- „Jeżeli prezydent Rzeczypospolitej nie może przejściowo sprawować urzędu, zawiadamia o tym Marszałka Sejmu, który tymczasowo przejmuje obowiązki Prezydenta Rzeczypospolitej. Gdy Prezydent Rzeczypospolitej nie jest w stanie zawiadomić Marszałka Sejmu o niemożności sprawowania urzędu, wówczas o stwierdzeniu przeszkody w sprawowaniu urzędu przez Prezydenta Rzeczypospolitej rozstrzyga Trybunał Konstytucyjny na wniosek Marszałka Sejmu. W razie uznania przejściowej niemożności sprawowania urzędu przez Prezydenta Rzeczypospolitej Trybunał Konstytucyjny powierza Marszałkowi Sejmu tymczasowe wykonywanie obowiązków Prezydenta Rzeczypospolitej" (art. 131. 1).

Dążenie do precyzji obserwujemy także w wysłowieniu okoliczności, w których norma prawna znajdzie zastosowanie - najczęściej do wska- 
zania okoliczności korzysta się z konstrukcji warunkowych ze spójnikiem jeżeli lub wyrażeniem $w$ razie, np.:

- „Jeżeli w ciągu 4 miesięcy od dnia przedłożenia Sejmowi projektu ustawy budżetowej nie zostanie ona przedstawiona Prezydentowi Rzeczypospolitej do podpisu, Prezydent może w ciągu 14 dni zarządzić skrócenie kadencji Sejmu" (art. 225).

- „Jeżeli w czasie stanu wojennego Sejm nie może zebrać się na posiedzenie, Prezydent Rzeczypospolitej na wniosek Rady Ministrów wydaje rozporządzenia $\mathrm{z}$ mocą ustawy $\mathrm{w}$ zakresie i w granicach określonych w 63art. 228 ust. 3-5. Rozporządzenia te podlegają zatwierdzeniu przez Sejm na najbliższym posiedzeniu" (art. 234).

- „W razie niepowołania Rady Ministrów w trybie 63rt. 154 ust. 3 Prezydent Rzeczypospolitej w ciągu 14 dni powołuje Prezesa Rady Ministrów i na jego wniosek pozostałych członków Rady Ministrów oraz odbiera od nich przysięgę...” (art. 155. 1.).

- „W razie nieudzielenia Radzie Ministrów wotum zaufania w trybie określonym w ust. 1, Prezydent Rzeczypospolitej skraca kadencję Sejmu i zarządza wybory (art. 155. 2.).

Prawodawca przewiduje sytuacje potencjalne, by w razie ich zaistnienia adresat normy miał pewność, jak ma się zachować, jakie działania podjąć, aby były prawnie ważne. Projektowanie sytuacji potencjalnych i wyznaczanie zachowań adresatów norm w razie ich zaistnienia jest niezbędne dla zachowania ciągłości działania organów państwa, a także dla zachowania trwałości konstytucji.

Jednym z wyróżników stylu tekstów prawnych jest idiomatyczność (Zieliński 2002: 95-102). Każda z konstytucji polskich miała sobie tylko właściwe połączenia wyrazowe. Zauważa się także idiomy wspólne, występujące w kilku ustawach zasadniczych (dobro państwa, dobro Ojczyzny). Dla Konstytucji RP charakterystyczne są następujące stałe połączenia wyrazowe: demokratyczne państwo prawne, działanie na podstawie $i w$ granicach prawa, równowaga wladzy ustawodawczej, władzy wykonawczej $i$ władzy sądowniczej, decentralizacja władzy publicznej, społeczna gospodarka rynkowa, przyrodzona godność człowie$k a$, wolność sumienia i religii, dobro wspólne itd. Można powiedzieć, że zawierają one fundamentalne zasady prawne. Zwracają uwagę także 
zdania - maksymy, w których w skondensowany sposób wysłowione są najważniejsze wartości państwa, np.:

- „Rzeczpospolita Polska jest demokratycznym państwem prawnym urzeczywistniającym zasady sprawiedliwości społecznej (art. 2).

- Konstytucja jest najwyższym prawem Rzeczypospolitej Polskiej (art. 8).

- Wszyscy są wobec prawa równi (art. 32).

\section{Styl preambuły}

Odmienną stylistykę ma wstęp konstytucyjny. Charakteryzuje go styl wysoki, uroczysty, co związane jest z funkcją tego segmentu konstytucji. Preambuła jest deklaracją intencji ustrojodawcy, aktem o charakterze ideologiczno-politycznym, jednocześnie eksplicytną informacją o najważniejszych wartościach państwa. Jest wypowiedzią ciągłą (bez podziału na mniejsze numerowane jednostki tekstu w przeciwieństwie do artykułowanego tekstu zasadniczego), wzniosłą, patetyczną, aktem perswazji emocjonalnej niespotykanym w innych aktach prawnych. Tomasz Gizbert-Studnicki stwierdza, że ,preambuły apelują raczej do uczuć odbiorców tekstu prawnego niż do ich intelektu, a zatem mamy do czynienia z perswazją emocjonalną, a nie racjonalną" (Gizbert-Studnicki 1986: 63). Zdaniem tego prawnika preambuły „pełnią funkcję narzędzi niestanowczych wspierających oddziaływania stanowcze zasadniczego tekstu prawnego" (Tamże: 63).

Wstęp do Konstytucji RP dobitnie wskazuje, że ustawa zasadnicza pochodzi od Narodu Polskiego - podmiotem mówiącym jest „My, Naród Polski" (identycznie w Konstytucji marcowej z 1921 r.). Ustrojodawca stwierdza, że najważniejszym podmiotem i suwerenem państwa polskiego są: „wszyscy obywatele Rzeczypospolitej, zarówno wierzący w Boga będącego źródłem prawdy, sprawiedliwości, dobra i piękna, jak i nie podzielający tej wiary, a te uniwersalne wartości wywodzący z innych źródeł..."

Rozwlekłość, którą zauważamy w doprecyzowaniu wyrażenia wszyscy obywatele jest próbą pogodzenia różnych wartości bliskich Polakom, jest wynikiem kompromisu osiągniętego podczas prac redak64 
cyjnych (nie chciano w preambule umieszczać apostrofy sakralnej, o którą upominała się prawicowo zorientowana część społeczeństwa).

Preambuła do Konstytucji RP jest wypowiedzią dwuwypowiedzeniową, ale semantycznie składa się z 3 części. Pierwsza (najdłuższa) jest deklaracją intencji, druga - aktem stanowienia ustawy zasadniczej, trzecia ma charakter apelu do wszystkich Polaków o przyjęcie konstytucji i przestrzeganie jej zasad. Pierwsze wypowiedzenie (obejmuje semantyczną część I i II) przypomina okres retoryczny (zob. Ziomek 1990: 269-288, por. Korolko 1990: 122-123). Nie wdając się w dyskusję na temat periodu retorycznego, przyjmuję, że skoro najistotniejszą jego cechą jest „zawieszenie sensu” przez wzmożenie napięcia i ciekawości, po którym następuje spadek i dopełnienie, to można uznać, że preambuła konstytucyjna jest wypowiedzią wystylizowaną na okres retoryczny, wypowiedzią periopodobną. Jest to okres dwuczłonowy. Człon I (protasis) jest bardzo rozbudowany (obejmuje 19 wersów, w które wpisane jest 13 odcinków treściowych - każdy z nich jest jednością myślową), natomiast człon II (apodosis) jest krótki, jednoodcinkowy (4 wersy). Większość odcinków protasis zbudowana jest podobnie, rozpoczyna się imiesłowem lub przymiotnikiem odczasownikowym (odzyskawszy, nawiązując, pragnąc, wdzięczni złączeni, świadomi, pomni), wewnątrz odcinków występują przydawki imiesłowowe (wierzacy, wywodzący, nie podzielajacy). Dominacja konstrukcji werbalnych ma wpływ na dynamikę wypowiedzi, wzmaga napięcie, buduje dramaturgię. Temu służy też zwielokrotnienie protasis - przedłuża oczekiwanie na apodosis. Rozpoczynający apodosis performatyw ustanawiamy, semantycznie jest najważniejszą częścią preambuły, jest aktem kreowania nowej rzeczywistości prawnej, stanowienia nowej ustawy zasadniczej. Część finalna wstępu konstytucyjnego ma charakter apelu (odezwy) skierowanego do:

„Wszystkich, którzy dla dobra Trzeciej Rzeczypospolitej tę Konstytucję będą stosowali, aby czynili to, dbając o zachowanie przyrodzonej godności człowieka, jego prawa do wolności i obowiązku solidarności z innymi, a poszanowanie tych zasad mieli za niewzruszoną podstawę Rzeczypospolitej Polskiej”.

Leksyka preambuły z 1997 r. ujawnia expressis 65verbis najważniejsze wartości państwa demokratycznego: poszanowanie wolności i sprawiedliwości, współdziałanie władz, dialog społeczny, dobro Trze- 
ciej Rzeczypospolitej, dbanie o zachowanie przyrodzonej godności człowieka, jego prawa do wolności i obowiązku solidarności z innymi, zagwarantowanie praw obywatelskich, rzetelność i sprawność działania instytucji publicznych.

\section{Zakończenie}

Na zakończenie warto zwrócić uwagę na wplatanie w tekst zasadniczy, pisany suchym normatywnym stylem, wypowiedzi uroczystych, pisanych stylem podniosłym. Są to teksty ślubowań posłów (wygłaszane w Sejmie przed rozpoczęciem sprawowania mandatu) oraz tekst przysięgi prezydenta (składany wobec Zgromadzenia Narodowego przed przyjęciem urzędu). Te uroczyste obowiązkowe akty mowy zawierają leksemy o wysokim ładunku aksjologicznym. Nawiązują do wartości najistotniejszych dla wspólnoty państwowej, wyrażonych wcześniej w preambule. Ślubowanie poselskie jest aktem zobowiązania do wykonywania obowiązków posła dla dobra obywateli i dla pomyślności ojczyzny:

„Uroczyście ślubuję rzetelnie i sumiennie wykonywać obowiązki wobec Narodu, strzec suwerenności i interesów Państwa, czynić wszystko dla pomyślności Ojczyzny i dobra obywateli, przestrzegać Konstytucji i innych praw Rzeczypospolitej” (art. 104. 2).

Przysięga prezydenta, jeszcze bardziej niż posła, nasycona jest leksemami wysokiego lotu: godność Narodu, wierność postanowieniom Konstytucji, niepodległość i bezpieczeństwo państwa, dobro Ojczyzny:

„Obejmując z woli Narodu urząd Prezydenta Rzeczypospolitej Polskiej, uroczyście przysięgam, że dochowam wierności postanowieniom Konstytucji, będę strzegł niezłomnie godności Narodu, niepodległości i bezpieczeństwa Państwa, a dobro Ojczyzny oraz pomyślność obywateli będą dla mnie zawsze najwyższym nakazem" (art. 130). 
Konstytucja RP przewiduje możliwość zakończenia przysięgi prezydenta oraz ślubowań poselskich formułą odwołującą się do Boga: „Tak mi dopomóż Bóg”. Prośba skierowana do Boga o pomoc w dotrzymaniu zobowiązania nie jest obligatoryjna (była obowiązkowa w 1921 i w 1935 r.).

Z powyższych analiz wynika, że konstytucja w wymiarze stylistycznym jest wielobarwna. Wprawdzie dominuje władczy suchy styl normatywny z wysoką frekwencją nakazów, obowiązków i uprawnień, ale, w przeciwieństwie do innych gatunków sfery urzędowo-prawnej, silnie obecne są też elementy wysokiego, kunsztownego stylu retorycznego realizowanego nie tylko $\mathrm{w}$ preambule, ale także w uroczystych aktach ślubowań prezydenta i posłów. Te swoiste teksty w tekście (intertekstualność), podkreślają doniosłość konstytucji jako najważniejszego dla wspólnoty państwowej aktu prawnego, aktu będącego „fundamentem porządku prawnego i organizacji władzy publicznej" (Sagan 2003: 18).

Na styl gatunkowy konstytucji mają również wpływ przekonania ideologiczne podmiotu prawodawczego (w najwyższym stopniu zaważyły one na stylu Konstytucji PRL), w obecnie obowiązującej ustawie zasadniczej mają one jednak wpływ przede wszystkim na komponent aksjologiczny (szerzej Malinowska 2012: 119-142).

\section{Bibliografia}

Bałaban, Andrzej. 1997. Funkcje konstytucji. W Charakter i struktura norm konstytucji, red. Jerzy Trzciński. Warszawa: PWN.

Gajda, Stanisław. 1993. Gatunkowe wzorce wypowiedzi. W Encyklopedia kultury polskiej XX wieku, t.2: Współczesny język polski, red. Jerzy Bartmiński. Wrocław: PWN.

Gizbert-Studnicki, Tomasz. 1986. Język prawny z perspektywy socjolingwistycznej. Kraków: Wydawnictwo Uniwersytetu Jagiellońskiego.

Kompendium wiedzy o społeczeństwie, państwie i prawie. 1999. Red. Sławomira Wronkowska i Maria Zmierczak. Warszawa-Poznań. Korolko, Mirosław. 1990. Sztuka retoryki. Przewodnik encyklopedyczny. Warszawa: PWN. 
Malinowska, Ewa. 2012. Konstytucja jako gatunek tekstu prawnego. Opole: Wydawnictwo Uniwersytetu Opolskiego.

Sagan, Stanisław. 2003. Prawo konstytucyjne Rzeczypospolitej Polskiej. Warszawa: LexisNexis.

Witosz, Bożena. 2005. Genologia lingwistyczna. Zarys problematyki. Katowice: Wydawnictwo Uniwersytetu Śląskiego.

Wojtak, Maria. 2004. Gatunki prasowe. Lublin: Wydawnictwo UMCS.

Wojtak, Maria. 2007. Styl gatunku, styl gatunkowy a styl funkcjonalny w perspektywie analitycznej. W Gatunki mowy i ich ewolucja, t.3: Gatunek a odmiany funkcjonalne, red. Danuta Ostaszewska. Katowice: Wydawnictwo Uniwersytetu Śląskiego.

Wronkowska, Sławomira. 2007. O cechach języka tekstów prawnych. W: Język polskiej legislacji, czyli zrozumiatość przekazu a stosowanie prawa. Materiaty z konferencji zorganizowanej przez Komisje Kultury i Środków Przekazu oraz Komisję Ustawodaw$c z q$. Warszawa: Wydawnictwo Sejmowe.

Zieliński, Maciej. 2002. Wykładnia prawa. Zasady. Reguły.Wskazówki. Warszawa: LexisNexis.

Zieliński Maciej, Ziembiński Zygmunt. 1992. Dyrektywy i sposób ich wypowiadania. Warszawa: PWN.

Ziembiński, Zygmunt.1966. Logiczne podstawy prawoznawstwa. Warszawa: PWN.

Ziomek, Jerzy. 1990. Retoryka opisowa. Warszawa: PWN. 